\title{
Determinants of COVID-19 Death Rate in Europe: Empirical Analysis
}

\section{Czynniki wpływające na śmiertelność z powodu COVID-19 w Europie: analiza empiryczna}

\section{Serhii Kozlovskyi ${ }^{\star}$, Daria Bilenko ${ }^{\star \star}$, Oleksandr Dluhopolskyi ${ }^{\star \star \star}$, Serhii Vitvitskyi ${ }^{\star \star \star \star}$, Olha Bondarenko ${ }^{\star \star \star \star \star *}$, Oleksandr Korniichuk}

\author{
*Department of Entrepreneurship, Corporate and Spatial Economics, \\ Vasyl' Stus Donetsk National University, Vinnytsia, Ukraine \\ E-mail: s.kozlovskyy@donnu.edu.ua, ORCID:0000-0003-0707-4996 \\ **Department of Finance named after L.l. Tarangul, \\ University of State Fiscal Service of Ukraine, Irpin, Ukraine \\ E-mail: belenkodaria1@gmail.com,ORCID:0000-0002-6220-8101 \\ ***Department of Economics and Economic Theory, \\ West Ukrainian National University, Ternopil, Ukraine \\ E-mail: dlugopolsky77@gmail.com,ORCID:0000-0002-2040-8762 \\ ****Department of Legal Disciplines, Donetsk Law Institute of the Ministry of \\ Internal Affairs of Ukraine, Kryvyi Rih, Ukraine \\ E-mail: vitvitskyi_ss@ukr.net, 0000-0002-4884-1883 \\ *****Department of Civil, Labor Law and Social Security Law, Donetsk Law Institute of the \\ Ministry of Internal Affairs, Mariupol, Ukraine \\ E-mail: olya-bondarenko@ukr.net, ORCID:0000-0002-3361-2121 \\ ******Institute of Feed and Agriculture of Podillya National Academy \\ of Agrarian Sciences of Ukraine, Vinnytsia, Ukraine \\ E-mail: fri@mail.vinnica.ua
}

\begin{abstract}
At the end of 2019, the new virus called Coronavirus disease (COVID-19) spread widely from China all over the world (including Europe). Most countries in Europe at the beginning of 2020 have been quarantined. The aim of the work is to develop the system dynamics model for assessing the impact of the different factors on the COVID19 death rate in Europe. There were tested three hypotheses about factors of reducing the COVID-19 death rate with the help of linear regression analysis. The density of the population of European countries doesn't affect the COVID-19 death rate. Also, COVID-19 death rate does not drastically affect mortality statistics. But the level of country's economic development is a factor of COVID-19 death rate because in high developed countries the pandemic death rate is lower, regardless of the mechanisms of the spread of the disease and its impact on human health.
\end{abstract}

Key words: COVID-19, coronavirus pandemic, death rate, economic development, GDP, regression 


\section{Streszczenie}

Z końcem 2019 r. nowy wirus COVID-19 rozprzestrzenił się z Chin po całym świecie (w tym po Europie). Większość krajów europejskich wiosną 2020 r. wprowadziła powszechną kwarantannę. Celem tej pracy jest opracowanie modelu dynamiki systemu pozwalającego określić wpływ różnych czynników na śmiertelność z powodu koronawirusa w Europie. Za pomocą analizy regresji liniowej sprawdzono trzy hipotezy dotyczące czynników zmniejszających śmiertelność COVID-19. Jak się okazuje, gęstość zaludnienia w różnych krajach europejskich nie wpływa na śmiertelność z powodu COVID-19. Ponadto śmiertelność z powodu koronawirusa nie zwiększa w znaczący sposób ogólnych statystyk śmiertelności. Natomiast poziom rozwoju gospodarczego kraju jest już czynnikiem wpływającym na śmiertelności z powodu COVID-19, ponieważ w krajach wysoko rozwiniętych śmiertelność w wyniku pandemii jest niższa, niezależnie od mechanizmów rozprzestrzeniania się choroby i jej wpływu na zdrowie ludzi.

Słowa kluczowe: COVID-19, pandemia koronawirusa, śmiertelność, rozwój ekonomiczny, GDP, regresja

\section{Introduction}

Almost every ten years there is a pandemic - the spread of a new disease that covers most of the world. The pandemic's consequences are usually more pronounced than epidemics because people don't have previously formed immunity to the new virus, which leads to at least 500 thousand deaths annually. Despite the fact that the first pandemics were recorded in the $430^{\text {th }}$ century $\mathrm{BC}$ and recur periodically, the new global pandemic of the coronavirus infection COVID-19, recorded by China in 2019, is unprecedented in the scale and rate of infection, and also the stringency of quarantine mandatory methods which were taken in most countries of the world. In Europe, which was declared by WHO as the center of the pandemic, only Belarus and Sweden were not severely restricted. For the first time in mankind's history, citizens of all countries of the world have the same recommendations to adhere to the social distance and wear masks, which is strictly implemented in all civilized countries.

A feature of the new viruses is that there is no information about the mechanisms of the spread of the disease and its impact on human health. The accumulation of information about the symptoms of the disease, the form of its course and consequences occurs in real-time. The main tool for analyzing the dynamics of the spread of a new virus, including COVID-19, is statistics (CRC, 2020), which helps to identify the causes of differences in the course of diseases in different countries and to determine the direction of measures to prevent the virus's spread. The focus on sustainable development problems in international context over the past few decades has raised questions about the impact of COVID-19 on sustainable development goals and their transformation. For example, a global pandemic and the closure of many businesses around the world could increase global poverty by $8 \%$ (even though from 1990 to 2015 its level decreased from 36 to $10 \%$ of the world's population) (The Sustainable Development Goals, 2020). Sustainable development goals and COVID-19 responses are shown in table 1 .
The rapid development of computer technologies and methods for analyzing big data makes it possible not only to collect and process the information on the number of cases, recovered and died from COVID19 but also to present data in the form of dashboards in the public domain to all Internet users. But even the availability of exhaustive statistics does not allow to explain clearly the factors affecting the dynamics of the disease's spread without using special analysis and modeling tools.

To illustrate this statement, in fig. 1 it is shown the statistics on the number of deaths from coronavirus in 20 European countries (10 countries - with the highest mortality rate, 10 countries - with the lowest mortality rate).

Regarding population density as a factor that does not provide social distance, in Iceland where population density is 3,4, COVID-19 rate death is 117,9 . In France population density is 122,6, COVID-19 rate death is lower. If we analyze such a factor as hospital beds per thousand, then in Belarus, where the number of deaths is 443 , the number of hospital beds available for every 1000 inhabitants is the highest among analyzed countries, and in Denmark the number of hospital beds is the lowest. It does not mean that lack of the hospital beds does not allow handling a surge of coronavirus patients. In Moldova and Montenegro COVID-19 rate death is approximately the same, but GDP per capita in Moldova is 3 times less than in Montenegro. A comparison of these two countries does not allow to draw an unambiguous conclusion that the economic well-being of a country affects the number of deaths.

At the beginning of November 2020, because of the new COVID-19 wave, the total number of death of COVID-19 in European countries has changed extremely (Johns Hopkins CRC, 2020): Belarus (995), Belgium (12331), Bosnia and Herzegovina (1358), Bulgaria (1466), Denmark (729), France (38728), Iceland (17), Ireland (1930), Italy (39764), Latvia (85), Lithuania (182), Moldova (1851), Montenegro (326), Netherlands (7748), Norway (282), Romania (7419), Russia (28996), Switzerland (2555), Ukraine (7952), United Kingdom (47832). 
Table 1. COVID-19 impact and response, authors aggregations based on (The Sustainable Development Goals, 2020; COVID19 (SARS-COV-2) vs Influenza Data, 2020)

\begin{tabular}{|c|c|c|c|}
\hline No & $\begin{array}{c}\text { Sustainable } \\
\text { Development Goal }\end{array}$ & $\begin{array}{c}\text { Potential } \\
\text { threats }\end{array}$ & Response \\
\hline 1. & No poverty & $\begin{array}{l}\text { The COVID-19 crisis risks reversing decades } \\
\text { of progress in the fight against poverty. The } \\
\text { global pandemic could increase global poverty } \\
\text { by as much as } 0,5 \text { billion people, or } 8 \% \text { of the } \\
\text { total human population. }\end{array}$ & $\begin{array}{l}\text { The UN COVID-19 Response and Recovery } \\
\text { Fund aims to specifically support low- and } \\
\text { middle-income countries as well as } \\
\text { vulnerable groups who are } \\
\text { disproportionately bearing the socio- } \\
\text { economic impacts of the pandemic. }\end{array}$ \\
\hline 2. & Zero hunger & $\begin{array}{l}\text { The number of people who suffer from hunger } \\
\text { began to slowly increase in } 2015 \text {. The number } \\
\text { of people affected by hunger would surpass } \\
840 \text { million by } 2030 \text {. }\end{array}$ & $\begin{array}{l}\text { The Food and Agriculture Organization } \\
\text { urges countries to: meet the immediate food } \\
\text { needs of their vulnerable populations, boost } \\
\text { social protection programs, keep global food } \\
\text { trade going, keep the domestic supply chain } \\
\text { gears moving, support smallholder farmers' } \\
\text { ability to increase food production. }\end{array}$ \\
\hline 3. & $\begin{array}{l}\text { Good health and } \\
\text { well-being }\end{array}$ & $\begin{array}{l}\text { COVID-19 is spreading human suffering, } \\
\text { destabilizing the global economy, and } \\
\text { upending the lives of billions of people. The } \\
\text { pandemic provides a watershed moment for } \\
\text { health emergency preparedness and for } \\
\text { investment in critical } 21^{\text {st }} \text { century public } \\
\text { services. }\end{array}$ & $\begin{array}{l}\text { The World Health Organization (WHO) has } \\
\text { been leading the global effort to tackle } \\
\text { COVID-19. The Strategic Preparedness and } \\
\text { Response Plan provides guidance for the } \\
\text { public health response to COVID-19 at } \\
\text { national and subnational levels and } \\
\text { highlights the coordinated support that is } \\
\text { required from the international community } \\
\text { to meet the challenge of COVID-19. }\end{array}$ \\
\hline 4. & Quality education & $\begin{array}{l}\text { In } 2020 \text {, as the COVID- } 19 \text { pandemic spread } \\
\text { across the globe, most countries announced } \\
\text { the temporary closure of schools, impacting } \\
\text { more than } 91 \% \text { of students worldwide. By the } \\
\text { middle of } 2020 \text {, close to } 1,6 \text { billion children } \\
\text { and youth were out of school. }\end{array}$ & $\begin{array}{l}\text { To protect the well-being of children and } \\
\text { ensure they have access to continued } \\
\text { learning, UNESCO in March } 2020 \text { launched } \\
\text { the COVID-19 Global Education Coalition, } \\
\text { what aims to: help countries in mobilizing } \\
\text { resources and implementing innovative and } \\
\text { context-appropriate solutions to provide } \\
\text { education remotely, leveraging hi-tech, low- } \\
\text { tech and no-tech approaches; seek equitable } \\
\text { solutions and universal access; ensure } \\
\text { coordinated responses and avoid } \\
\text { overlapping efforts; } \\
\text { Facilitate the return of students to school } \\
\text { when they reopen to avoid an upsurge in } \\
\text { dropout rates. }\end{array}$ \\
\hline 5 . & Gender equality & $\begin{array}{l}\text { The effects of the COVID- } 19 \text { pandemic could } \\
\text { reverse the limited progress that has been } \\
\text { made on gender equality and women's rights. } \\
\text { The coronavirus outbreak exacerbates existing } \\
\text { inequalities for women and girls across every } \\
\text { sphere - from health and the economy, to } \\
\text { security and social protection. }\end{array}$ & $\begin{array}{l}\text { Every COVID-19 response plan, and every } \\
\text { recovery package and budgeting of } \\
\text { resources, needs to address the gender } \\
\text { impacts of this pandemic. This means: 1) } \\
\text { including women and women's } \\
\text { organizations in COVID-19 response } \\
\text { planning and decision-making; 2) } \\
\text { transforming the inequities of unpaid care } \\
\text { work into a new, inclusive care economy } \\
\text { that works for everyone; } 3 \text { ) designing socio- } \\
\text { economic plans with an intentional focus on } \\
\text { the lives and futures of women and girls. }\end{array}$ \\
\hline 6. & $\begin{array}{l}\text { Clean water and } \\
\text { sanitation }\end{array}$ & $\begin{array}{l}\text { The COVID-19 pandemic has demonstrated } \\
\text { the critical importance of sanitation, hygiene, } \\
\text { and adequate access to clean water for } \\
\text { preventing and containing diseases. Hand } \\
\text { hygiene saves lives. }\end{array}$ & $\begin{array}{l}\text { UNICEF is urgently appealing for funding } \\
\text { and support to reach more girls and boys } \\
\text { with basic water, sanitation and hygiene } \\
\text { facilities. }\end{array}$ \\
\hline 7. & $\begin{array}{l}\text { Affordable and } \\
\text { clean energy }\end{array}$ & $\begin{array}{l}\text { Access to electricity in poorer countries has } \\
\text { begun to accelerate, energy efficiency } \\
\text { continues to improve, and renewable energy is } \\
\text { making impressive gains in the electricity } \\
\text { sector. Nevertheless, more focused attention is } \\
\text { needed to improve access to clean and safe } \\
\text { cooking fuels and technologies for } 3 \text { billion } \\
\text { people, to expand the use of renewable energy } \\
\text { beyond the electricity sector. }\end{array}$ & $\begin{array}{l}\text { Three ways to respond to the COVID-19 } \\
\text { emergency: prioritize energy solutions to } \\
\text { power health clinics and first responders; } \\
\text { keep vulnerable consumers connected; } \\
\text { increase reliable, uninterrupted, and } \\
\text { sufficient energy production in preparation } \\
\text { for a more sustainable economic recovery. }\end{array}$ \\
\hline
\end{tabular}




\begin{tabular}{|c|c|c|c|}
\hline No & $\begin{array}{c}\text { Sustainable } \\
\text { Development Goal }\end{array}$ & $\begin{array}{c}\text { Potential } \\
\text { threats }\end{array}$ & Response \\
\hline 8. & $\begin{array}{l}\text { Decent work and } \\
\text { economic growth }\end{array}$ & $\begin{array}{l}\text { COVID- } 19 \text { has disrupted billions of lives and } \\
\text { endangered the global economy. As job losses } \\
\text { escalate, nearly half of the global workforce is } \\
\text { at risk of losing their livelihoods. }\end{array}$ & $\begin{array}{l}\text { The socio-economic response framework } \\
\text { consists of five streams of work: ensuring } \\
\text { that essential health services are still } \\
\text { available and protecting health systems; } \\
\text { helping people cope with adversity, through } \\
\text { social protection and basic services; } \\
\text { protecting jobs, supporting small and } \\
\text { medium-sized enterprises, and informal } \\
\text { sector workers through economic response } \\
\text { and recovery programs; guiding the } \\
\text { necessary surge in fiscal and financial } \\
\text { stimulus to make macroeconomic policies } \\
\text { work for the most vulnerable and } \\
\text { strengthening multilateral and regional } \\
\text { responses; promoting social cohesion and } \\
\text { investing in community-led resilience and } \\
\text { response systems }\end{array}$ \\
\hline 9. & $\begin{array}{l}\text { Industry, } \\
\text { innovation, and } \\
\text { infrastructure }\end{array}$ & $\begin{array}{l}\text { Global manufacturing growth has been } \\
\text { steadily declining, even before the outbreak of } \\
\text { the COVID- } 19 \text { pandemic. The pandemic is } \\
\text { hitting manufacturing industries hard and } \\
\text { causing disruptions in global value chains and } \\
\text { the supply of products. The coronavirus } \\
\text { pandemic has revealed the urgent need for } \\
\text { resilient infrastructure. }\end{array}$ & $\begin{array}{l}\text { Information and communication } \\
\text { technologies have been on the frontlines of } \\
\text { the COVID-19 response. The crisis has } \\
\text { accelerated the digitalization of many } \\
\text { businesses and services, including } \\
\text { teleworking and video conferencing systems } \\
\text { in and out of the workplace, as well as access } \\
\text { to healthcare, education and essential goods } \\
\text { and services. }\end{array}$ \\
\hline 10. & $\begin{array}{l}\text { Reduced } \\
\text { inequalities }\end{array}$ & $\begin{array}{l}\text { COVID-19 has deepened existing inequalities, } \\
\text { hitting the poorest and most vulnerable } \\
\text { communities the hardest. COVID-19 } \\
\text { pandemic has significantly increased global } \\
\text { unemployment and dramatically slashed } \\
\text { workers' incomes. }\end{array}$ & $\begin{array}{l}\text { To ensure that people everywhere have } \\
\text { access to essential services and social } \\
\text { protection, the UN has called for an } \\
\text { extraordinary scale-up of international } \\
\text { support and political commitment, including } \\
\text { funding through the UN COVID-19 } \\
\text { Response and Recovery Fund which aims to } \\
\text { support low- and middle-income countries } \\
\text { and vulnerable groups who are } \\
\text { disproportionately bearing the socio- } \\
\text { economic impacts of the pandemic. }\end{array}$ \\
\hline 11. & $\begin{array}{l}\text { Sustainable cities } \\
\text { and communities }\end{array}$ & $\begin{array}{l}\text { Rapid urbanization is resulting in a growing } \\
\text { number of slum dwellers, inadequate and } \\
\text { overburdened infrastructure, and services, } \\
\text { worsening air pollution and unplanned urban } \\
\text { sprawl. The impact of COVID-19 will be most } \\
\text { devastating in poor and densely populated } \\
\text { urban areas, especially for the one billion } \\
\text { people living in informal settlements and } \\
\text { slums worldwide, where overcrowding also } \\
\text { makes it difficult to follow recommended } \\
\text { measures such as social distancing and self- } \\
\text { isolation. }\end{array}$ & $\begin{array}{l}\text { UN-Habitat, the UN agency for housing and } \\
\text { urban development, is working with } \\
\text { national and local governments to help them } \\
\text { prepare for, prevent, respond to and recover } \\
\text { from the COVID-19 pandemic. The UN } \\
\text { Habitat COVID-19 Response Plan aims to: } \\
\text { support local governments and community- } \\
\text { driven solutions in informal settlements, } \\
\text { provide urban data, evidence-based } \\
\text { mapping and knowledge for informed } \\
\text { decision, mitigate economic impact and } \\
\text { initiate recovery. }\end{array}$ \\
\hline 12. & $\begin{array}{l}\text { Responsible } \\
\text { consumption and } \\
\text { production }\end{array}$ & $\begin{array}{l}\text { Economic and social progress over the last } \\
\text { century has been accompanied by } \\
\text { environmental degradation that is endangering } \\
\text { the very systems on which our future } \\
\text { development. The COVID-19 pandemic offers } \\
\text { countries an opportunity to build recovery } \\
\text { plans that will reverse current trends and } \\
\text { change our consumption and production } \\
\text { patterns towards a more sustainable future. }\end{array}$ & $\begin{array}{l}\text { COVID-19 can be a catalyst for social } \\
\text { change. People must build back better and } \\
\text { transition production and consumption } \\
\text { patterns towards more sustainable practices. }\end{array}$ \\
\hline 13. & Climate action & $\begin{array}{l}\text { Climate change is affecting every country on } \\
\text { every continent. It is disrupting national } \\
\text { economies and affecting lives. Although } \\
\text { greenhouse gas emissions are projected to } \\
\text { drop about } 6 \% \text { in } 2020 \text { due to travel bans and } \\
\text { economic slowdowns resulting from the } \\
\text { COVID- } 19 \text { pandemic, this improvement is } \\
\text { only temporary. }\end{array}$ & $\begin{array}{l}\text { Saving lives and livelihoods requires urgent } \\
\text { action to address both the pandemic and the } \\
\text { climate emergency. }\end{array}$ \\
\hline
\end{tabular}




\begin{tabular}{|c|c|c|c|}
\hline No & $\begin{array}{c}\text { Sustainable } \\
\text { Development Goal }\end{array}$ & $\begin{array}{c}\text { Potential } \\
\text { threats }\end{array}$ & Response \\
\hline 14. & Life below water & $\begin{array}{l}\text { At the current time, there is a continuous } \\
\text { deterioration of coastal waters owing to } \\
\text { pollution, and ocean acidification is having an } \\
\text { adversarial effect on the functioning of } \\
\text { ecosystems and biodiversity. }\end{array}$ & $\begin{array}{l}\text { The ocean can be an ally against COVID-19: } \\
\text { bacteria found in the depths of the ocean are } \\
\text { used to carry out rapid testing to detect the } \\
\text { presence of COVID-19. And the diversity of } \\
\text { species found in the ocean offers great } \\
\text { promise for pharmaceuticals. }\end{array}$ \\
\hline 15. & Life on land & $\begin{array}{l}\text { Deforestation and desertification - caused by } \\
\text { human activities and climate change - pose } \\
\text { major challenges to sustainable development } \\
\text { and have affected the lives and livelihoods of } \\
\text { millions of people. }\end{array}$ & $\begin{array}{l}\text { The COVID-19 outbreak highlights the need } \\
\text { to address threats to ecosystems and } \\
\text { wildlife. UNEP's response covers four } \\
\text { areas: 1) helping nations manage COVID- } 19 \\
\text { waste, 2) delivering a transformational } \\
\text { change for nature and people, 3) working to } \\
\text { ensure economic recovery packages create } \\
\text { resilience to future crises, 4) modernizing } \\
\text { global environmental governance. }\end{array}$ \\
\hline 16. & $\begin{array}{l}\text { Peace, justice, and } \\
\text { strong institutions }\end{array}$ & $\begin{array}{l}\text { Conflict, insecurity, weak institutions, and } \\
\text { limited access to justice remain a great threat } \\
\text { to sustainable development. }\end{array}$ & $\begin{array}{l}\text { Human rights put people center-stage. } \\
\text { Responses that are shaped by and respect } \\
\text { human rights result in better outcomes in } \\
\text { beating the pandemic, ensuring healthcare } \\
\text { for everyone, and preserving human dignity. }\end{array}$ \\
\hline 17. & $\begin{array}{l}\text { Partnerships for the } \\
\text { goals }\end{array}$ & $\begin{array}{l}\text { A successful development agenda requires } \\
\text { inclusive partnerships - at the global, } \\
\text { regional, national, and local levels - built } \\
\text { upon principles and values, and upon a shared } \\
\text { vision and shared goals placing people and the } \\
\text { planet at the center. Due to the COVID- } 19 \\
\text { pandemic, the global economy is projected to } \\
\text { contract sharply, by } 3 \% \text { in } 2020 \text {, experiencing } \\
\text { its worst recession since the Great Depression. }\end{array}$ & $\begin{array}{l}\text { To support efforts in low- and middle- } \\
\text { income countries, the UN Secretary-General } \\
\text { launched a UN Response and Recovery } \\
\text { Trust Fund. The UN set out a Global } \\
\text { Humanitarian Response Plan to assist the } \\
\text { most vulnerable populations. The World } \\
\text { Health Organization (WHO), the UN } \\
\text { Foundation and partners launched a first-of- } \\
\text { its-kind Solidarity Response Fund to allow } \\
\text { corporations and individuals to directly } \\
\text { contribute to WHO's COVID-19 response. }\end{array}$ \\
\hline
\end{tabular}

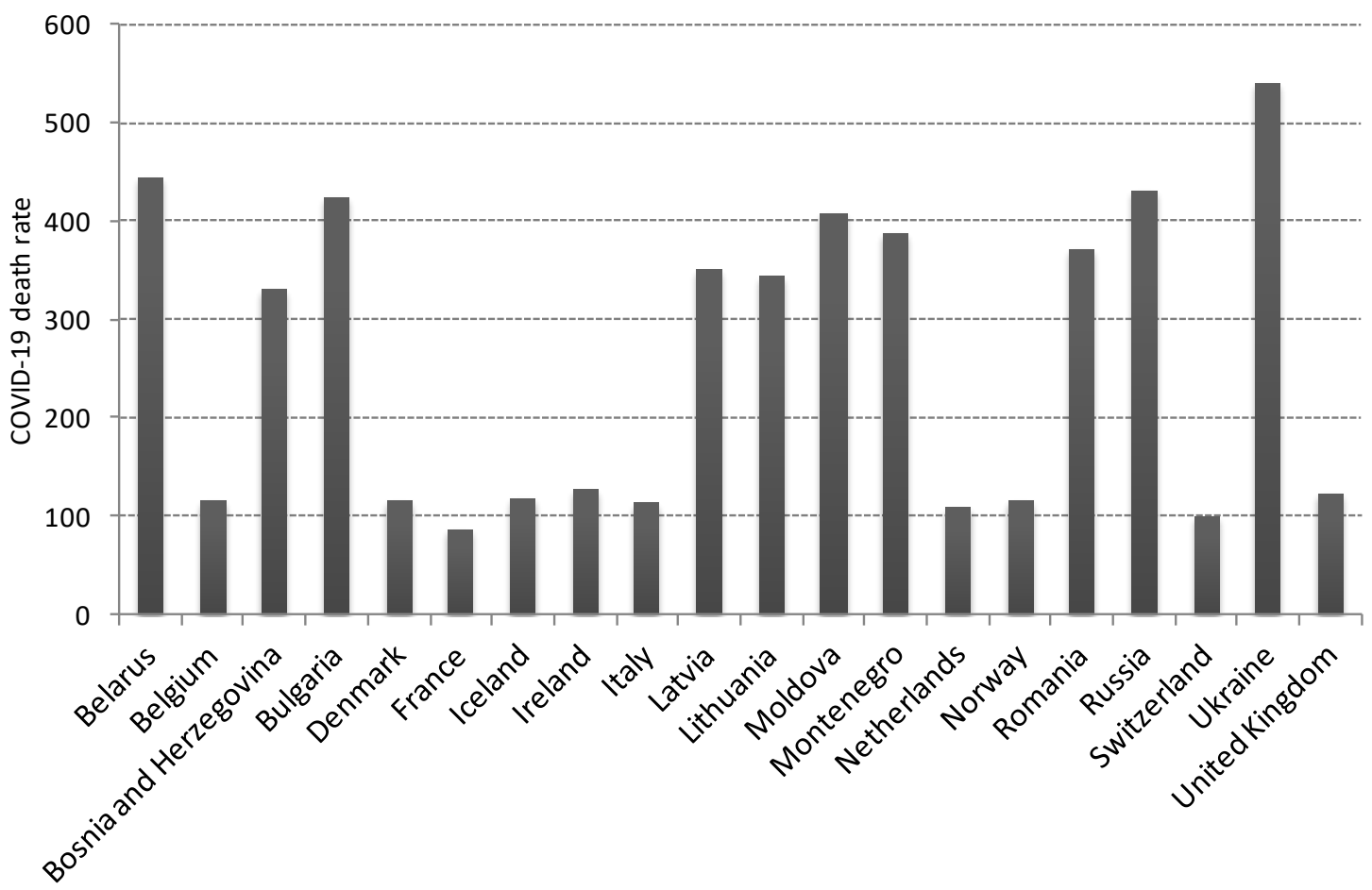

Figure 1. COVID-19 rate death in Europe in June, 2020 (Johns Hopkins CRC, 2020)

However, the presence of COVID-19 big data and statistical tools for assessing the influence of factors allows us to identify the factors that have the greatest impact on the mortality rate from COVID-19. Hence the aim of writing an article is to assess the impact of the different factors on the COVID-19 death rate. 


\section{Literature review}

Research issues in the field of counteracting the COVID-19 pandemic have been actively raised in scientific circles since the beginning of its spread outside China. The beginning of 2020 was marked by dramatic changes in the global economy through COVID-19. As a result, most countries around the world have introduced strict quarantine, associated not only with the regime of population's self-isolation, compliance with social distance, but also the suspension of entire industries (passenger transport, tourism, hotel, and restaurant business, etc.). This, of course, reflected in the labor market, social protection system, new business conditions, changes in public policy priorities in the short and long run, etc. It should be noted that in just ten months (from February to November 2020) the number of confirmed cases of COVID-19 infection increased from 12 thousand to 48 million people (Johns Hopkins CRC, 2020).

In a work prepared under the auspices of the World Bank (2020), case studies of individual countries of the EU, Eastern Europe and Central Asia on scenarios of coronavirus spread and possible options of the national economies' reaction to this global danger are analyzed. Although the recommendations for the population's reaction to the manifestations of various emergencies have long been known (IASC, 2007), only in 2020 the whole world did finally realize the danger of global pandemics.

For example, the study (Tran, Pham, Ngo, 2020) applies to develop a prediction model for the daily total confirmed cases of COVID-19, totally confirmed new cases, total deaths, total new deaths, the growth rate in confirmed cases, and growth rate in deaths. The research (Yadav, Maheshwari, Chandra, 2020) introduces the spreading pattern of COVID-19 in the top ten infected countries. The articles (Kozlovskyi, Bilenko, Kuzheliev et al., 2020; Masum, Pal, 2020; Caraka, Lee, Kurniawan et al., 2020; Gupta, Tomar, Kumar, 2020; Cohen, Normile, 2020; Xie, Naminse, Liu, Yi, 2020; Hamidi, Sabouri, Ewing, 2020; Koziuk, Hayda et al., 2020) analyzed the effect on various social and economic parameters by lockdown due to COVID-19 in India, Indonesia, China, EU and US.

The directions of the pandemic's impact on certain sectors of the national economies today are of considerable interest of researchers from around the world. Thus, the pandemic's impact on the future development of education in the XXI century and the progress of distance learning in different countries are considered in the numerous works (Minghat, Ana, Purnawarman et al., 2020; Klapkiv, Dluhopolska, 2020; Alsadoon, Turkestani, 2020; The potential of online learning for adults, 2020; Education and COVID-19, 2020; Santi, Gorghiu, Pribeanu, 2020; Berezhna, Prokopenko, 2020). Today a lot of digital learning management systems are actively used, for example CenturyTech, ClassDojo, Edmodo, Google Classroom, Moodle, Schoology, Seesaw, Skooler, Cell-Ed, Eneza Education, Funzi, KaiOS, Ustad Mobile (UNESCO, 2020). Features of online accreditations during a pandemic time in Ukraine are described in (Stukalo, Dluhopolskyi, 2020).

Regarding the aviation and space industries, the problems of their development for the next few years are described in (The impacts of COVID-19 on the space industry, 2020; Dluhopolskyi, 2020; Global Aviation Market 2020-2026; IATA, 2020). The sphere of global hospitality and tourism in the context of COVID-19 crisis is considered in the studies (COVID-19 and tourism, 2020; Tourism Policy Responses to the coronavirus, 2020; Coronavirus, 2020; Folinas, Metaxas, 2020; Gursoy, Chi, 2020).

The necessity of qualitative data analysis in the context of pandemic response is described in the studies (Al-Rousan, Al-Najjar, 2020; Bragazzi, Dai, Damiani et al., 2020). To predict how big the COVID-19 epidemic could get, researchers are studying different scenarios using simulation models (Kozlovskyi, Bilenko, Kuzheliev et al., 2020; Brauer, CastilloChavez, Feng, 2019). McKinsey Global Institute and Oxford Economics have modeled two scenarios of small businesses recovering in the US (Dua, Mahajan et al., 2020). According to the first (virus-contained) scenario, manufacturing, construction, retail trade, real estate, rental and leasing, information services, wholesale trade, utilities, finance, and insurance sectors will recover since the end of 2020 or beginning of 2021. Industries like accommodation and food services, mining, oil and gas extraction, arts, entertainment, and recreation will recover only since 2023. According to second (muted-contained) scenario, the recovering period for manufacturing, construction, retail trade, real estate, rental and leasing, information services, wholesale trade, utilities, finance, and insurance sectors will begin just since 2023 and for the accommodation and food services, quarrying, oil and gas extraction, arts, entertainment, and recreation industries will start only in 2025 .

Our scientific interest is how to assess the impact of the key factors on the COVID-19 death rate (case of Europe).

\section{Research methodology}

The main approaches for assessing the different factors impact on the COVID-19 death rate can be divided into three groups (WHO, 2020). The first group includes the opinion that the main reduce factor of the pandemic spread is to ensure social distance. Other scientists have focused on risk factors associated with the general health of the population, their age, and comorbidities. The third group includes the conclusion that the main factor that prevents the reduction of the consequences of pandemics is the high level of the country's economic development. And although high rates of economic 
growth don't contribute to a decrease in the incidence rate, they unequivocally indicate a lower number of deaths, because high standards in the health care system allow timely detection of the disease and provide the patient with quality treatment.

To prove these assumptions, we formulate three hypotheses:

Hypothesis 1 - ensuring social distance helps to reduce COVID-19 death rate;

Hypothesis 2 - high medical and demographic indicators help to reduce COVID-19 death rate;

Hypothesis 3 - high level of economic development helps to reduce COVID-19 death rate.

To test these hypotheses let run a linear regression analysis. Linear regression is a data plot that graphs the linear relationship between an independent variable and a dependent variable (Montgomery, Peck, Vining, 2012).

For all three hypotheses dependent variable is COVID-19 death rate. COVID-19 death rate is a measure of the number of COVID-19 deaths in a population of the country, scaled to the size of that population, per unit of time (Porta, 2014). The choice of the COVID-19 death rate as a dependent variable is due to the fact that the total COVID-19 cases depend on the number of COVID-19 tests.

Just a few countries in the world conduct mass testing of those with suspected coronavirus. Most countries are still forced to economize on tests against the background of an increase in patients and test patients only with pronounced symptoms. Each country has different laboratory capacities, requirements for private and public laboratories, and the degree of communication between hospitals and laboratories. At the same time, all COVID-19 mortality estimation is done using vital statistics. This makes COVID-19 death rate data more reliable.

For Hypothesis 1 it is proposed to use population density as an independent variable. Population density is a measurement of population per unit area. E. Pafka (Pafka, 2020) raised the question of what kind of density is relevant for the spread of COVID-19. It was proved that COVID-19 is mainly transmitted through extended close contact. In countries with a high population density, the ability to maintain social distance is impossible even under the quarantine regime. Human overpopulation means, that people with several families live in small apartments. Even in conditions of total quarantine and self-isolation, healthy and whitened people of the same family will be in enclosed spaces, where droplets and aerosols accumulate.

Hence, the regression equation for testing hypothesis 1 will look like this:

$Y=a+b_{1} * X_{1}$,

where $a, b_{1}-$ regression coefficients; $X_{1}$ - population density; $Y$-COVID-19 death rate.

Medical-demographic indicators are collected by the World Health Organization (WHO). It includes dis- eases and conditions, health personnel, immunization, reproductive health, etc. The core element of medical-demographic indicators is the classification of population by age. The older the country's population, the higher the COVID-19 death rate probability. A review of studies by WHO concludes that diabetes is associated with an increased risk of COVID19-related in-hospital death. It finds that one-third of COVID-19 -related deaths in hospitals in are individuals with diabetes. The other studies by WHO found that smokers are more likely to develop severe disease with COVID-19, compared to non-smokers (WHO statement, 2020).

The factors listed above are proposed to be included in the regression equation to test hypothesis 2 :

$Y=a+b_{1} * X_{1}+b_{2} * X_{2}+b_{3} * X_{3}$,

where $a, b_{1}, b_{2}, b_{3}$ - regression coefficients; $X_{1}$ - people aged 70 older; $X_{2}$ - diabetes prevalence; $X_{3}-$ smokers; $Y$ - COVID-19 death rate.

Hypothesis 3 suggests that the main factors for successfully overcoming the pandemic are a high level of economic development. A global measure for gauging the prosperity of country is a gross domestic product per capita (GDP per capita). GDP per capita is a measure of country wealth. It shows how much economic production value can be attributed to each inhabitant (Barro, 2020). Usually spent on health care is calculated as share spent percentage of GDP. But a higher GDP share spent does not lead to a better functioning health system. High spending can be explained by higher costs and prices. Therefore, it is proposed to use an indicator that provides a measure of the resources available for services to inpatients in hospitals in terms of number of beds that are maintained, staffed and available. The other important indicator of the health care system of a country is the number of beds per thousand. A summary measure of average achievement of human development such as a decent standard of living is a human development index.

For hypothesis 3 , the regression equation includes two independent variables (Kozlovskyi A. et al., 2020):

$Y=a+b_{1} * X_{1}+b_{2} * X_{2}+b_{3} * X_{3}$,

where a, b1, b2, b3 - regression coefficient; X1 gross domestic product per capita; X2 - hospital beds per thousand; $\mathrm{X}_{3}$ - human development index; Y - COVID-19 death rate.

The first step in running regression analysis is to collect data that contains the dependent variable COVID-19 death rate and the independent variables of each hypothesis. The next step is outputting a regression. Using the software tools for data analysis, creating a regression output is done automatically. Further it is necessary to interpret the results. The Rsquare, significance $\mathrm{F}$ and $\mathrm{p}$-values will allow proving or disproving the proposed hypotheses. The closer R-square to 1 , while the results are reliable (significance $\mathrm{F}$ ) and the regression model is a signif- 
Table 2. Data set of the three group of factors impact on the Covid-19 death rate in Europe as for October 2020, authors aggregations based on (Schellekens, Sourrouille, 2020; World Bank indicators, 2020; Worldometer, 2020)

\begin{tabular}{|c|c|c|c|c|c|c|c|c|c|}
\hline \multirow[b]{2}{*}{ No } & \multirow[b]{2}{*}{ Country } & \multirow[b]{2}{*}{$\begin{array}{l}\text { COVID-19 } \\
\text { death rate }\end{array}$} & \multirow{2}{*}{$\begin{array}{c}\text { Hypothesis } 1 \\
\text { Population } \\
\text { density }\end{array}$} & \multicolumn{3}{|c|}{ Hypothesis 2} & \multicolumn{3}{|c|}{ Hypothesis 3} \\
\hline & & & & $\begin{array}{c}\text { People aged } 70 \\
\text { older }\end{array}$ & $\begin{array}{c}\text { Diabetes } \\
\text { prevalence }\end{array}$ & Smokers & $\begin{array}{c}\text { GDP } \\
\text { per capita }\end{array}$ & $\begin{array}{c}\text { Hospital } \\
\text { beds per } \\
1000\end{array}$ & $\begin{array}{c}\text { Human } \\
\text { development } \\
\text { index }\end{array}$ \\
\hline 1 & Albania & 0,943 & 104,871 & 8,643 & 10,08 & 29,15 & 11803,431 & 2,89 & 0,785 \\
\hline 2 & Austria & 0,412 & 106,749 & 13,748 & 6,35 & 29,65 & 45436,686 & 7,37 & 0,908 \\
\hline 3 & Belarus & 0,59 & 46,858 & 9,788 & 5,18 & 28,3 & 17167,967 & 11 & 0,808 \\
\hline 4 & Belgium & 0,863 & 375,564 & 12,849 & 4,29 & 28,25 & 42658,576 & 5,64 & 0,916 \\
\hline 5 & $\begin{array}{l}\text { Bosnia and } \\
\text { Herzegovina }\end{array}$ & 2,656 & 68,496 & 10,711 & 10,08 & 38,95 & 11713,895 & 3,5 & 0,768 \\
\hline 6 & Bulgaria & 0,987 & 65,18 & 13,272 & 5,81 & 37,25 & 18563,307 & 7,454 & 0,813 \\
\hline 7 & Croatia & 0,905 & 73,726 & 13,053 & 5,59 & 37,1 & 22669,797 & 5,54 & 0,831 \\
\hline 8 & \begin{tabular}{|l|} 
Czech \\
Republic
\end{tabular} & 1,614 & 137,176 & 11,58 & 6,82 & 34,4 & 32605,906 & 6,63 & 0,888 \\
\hline 9 & Denmark & 0,222 & 136,52 & 12,325 & 6,41 & 19,05 & 46682,515 & 2,5 & 0,929 \\
\hline 10 & Estonia & 0,323 & 31,033 & 13,491 & 4,02 & 31,9 & 29481,252 & 4,69 & 0,871 \\
\hline 11 & Finland & 0,052 & 18,136 & 13,264 & 5,76 & 20,45 & 40585,721 & 3,28 & 0,92 \\
\hline 12 & France & 1,101 & 122,578 & 13,079 & 4,77 & 32,85 & 38605,671 & 5,98 & 0,901 \\
\hline 13 & Germany & 0,126 & 237,016 & 15,957 & 8,31 & 30,65 & 45229,245 & 8 & 0,936 \\
\hline 14 & Greece & 0,411 & 83,479 & 14,524 & 4,55 & 43,65 & 24574,382 & 4,21 & 0,87 \\
\hline 15 & Hungary & 1,242 & 108,043 & 11,976 & 7,55 & 30,8 & 26777,561 & 7,02 & 0,838 \\
\hline 16 & Ireland & 0,231 & 69,874 & 8,678 & 3,28 & 24,35 & 67335,293 & 2,96 & 0,938 \\
\hline 17 & Italy & 0,357 & 205,859 & 16,24 & 4,78 & 23,8 & 35220,084 & 3,18 & 0,88 \\
\hline 18 & Latvia & 0,151 & 31,212 & 14,136 & 4,91 & 38,3 & 25063,846 & 5,57 & 0,847 \\
\hline 19 & Lithuania & 0,157 & 45,135 & 13,778 & 3,67 & 29,65 & 29524,265 & 6,56 & 0,858 \\
\hline 20 & Luxembourg & 0,228 & 231,447 & 9,842 & 4,42 & 23,45 & 94277,965 & 4,51 & 0,904 \\
\hline 21 & Malta & 2,588 & 1454,037 & 11,324 & 8,83 & 25,55 & 36513,323 & 4,485 & 0,878 \\
\hline 22 & Moldova & 2,798 & 123,655 & 6,955 & 5,72 & 25,25 & 5189,972 & 5,8 & 0,7 \\
\hline 23 & Netherlands & 0,667 & 508,544 & 11,881 & 5,29 & 25,85 & 48472,545 & 3,32 & 0,931 \\
\hline 24 & Norway & 0,132 & 14,462 & 10,813 & 5,31 & 20,15 & 64800,057 & 3,6 & 0,953 \\
\hline 25 & Poland & 0,649 & 124,027 & 10,202 & 5,91 & 28,2 & 27216,445 & 6,62 & 0,865 \\
\hline 26 & Portugal & 0,588 & 112,371 & 14,924 & 9,85 & 23,15 & 27936,896 & 3,39 & 0,847 \\
\hline 27 & Romania & 1,701 & 85,129 & 11,69 & 9,74 & 30 & 23313,199 & 6,892 & 0,811 \\
\hline 28 & Russia & 1,012 & 8,823 & 9,393 & 6,18 & 40,85 & 24765,954 & 8,05 & 0,816 \\
\hline 29 & Slovakia & 0,288 & 113,128 & 9,167 & 7,29 & 30,4 & 30155,152 & 5,82 & 0,855 \\
\hline 30 & Slovenia & 0,275 & 102,619 & 12,93 & 7,25 & 22,55 & 31400,84 & 4,5 & 0,896 \\
\hline 31 & Switzerland & 0,083 & 214,243 & 12,644 & 5,59 & 25,75 & 57410,166 & 4,53 & 0,944 \\
\hline 32 & Ukraine & 1,431 & 77,39 & 11,133 & 7,11 & 30,45 & 7894,393 & 8,8 & 0,751 \\
\hline 33 & UK & 0,762 & 272,898 & 12,527 & 4,28 & 22,35 & 39753,244 & 2,54 & 0,922 \\
\hline
\end{tabular}

icantly good fit (p-values), the more likely the hypothesis can be accepted.

Thus, the method of testing hypotheses about factors that contribute to a decrease in COVID-19 death rate is regression analysis. For each of the hypotheses, a regression equation was proposed, the independent variables of which are factors influencing the distribution COVID-19. The hypothesis for which regression statistics will be the best, given a statistically significant conclusion, will be accepted.

\section{Results}

The most important issues in running regression analysis are to use reliable data based on publicly available. As such data resources, it is proposed to use Worldometer as a source of information (Worldometer, 2020). Worldometer analyzes, validates, and aggregates data from thousands of sources in real-time and provides global COVID-19 live statistics in 215 countries. Its data is trusted and used by government agencies, educational institutions, and the media (COVID-19 (SARS-CoV-2) vs influenza data, resources \& response, 2020).

Assessing the impact of the different factors on the Covid-19 death rate it is proposed to carry out the example of 37 European countries. The data was collected in June and October 2020 and summarized in the table 2.

Data set in table 1 is truly independent, does not have different error variances. It is proved with a Chisquare test and heteroskedasticity test. The error terms of each variable are not uncorrelated.

Regression analysis is run in EXCEL using the regression data analysis tool. EXCEL produces the summary output. Its result is displayed in table 3. The R-square value, also known as the coefficient of determination, measures the proportion of variation 
Table 3. A regression analysis result, authors calculations

\begin{tabular}{|l|l|c|c|c|c|c|c|}
\hline \multirow{2}{*}{ No } & & \multicolumn{2}{|c|}{ Hypothesis 1 } & \multicolumn{2}{c|}{ Hypothesis 2 } & \multicolumn{2}{c|}{ Hypothesis 3 } \\
\cline { 3 - 8 } & & June 2020 & $\begin{array}{c}\text { October } \\
2020\end{array}$ & June 2020 & $\begin{array}{c}\text { October } \\
2020\end{array}$ & June 2020 & $\begin{array}{c}\text { October } \\
2020\end{array}$ \\
\hline 1 & R-square & 0,2515 & 0,3718 & 0,6096 & 0,6107 & 0,8246 & 0,6572 \\
\hline 2 & Adjusted R-square & 0,0365 & 0,1382 & 0,3145 & 0,3730 & 0,6611 & 0,4319 \\
\hline 3 & Significance F & 0,1332 & 0,1332 & 0,0014 & 0,0033 & 0,00004 & 0,0008 \\
\hline
\end{tabular}

in the dependent variable (COVID-19 death rate) explained by the independent variable. For Hypothesis 1 R-square is interpreted as the percentage of COVID-19 death rate that can be explained by population density. It is approximately $25 \%$ of the observed variation can be explained by population density in June and $37 \%$ in October. For Hypothesis 2 the R-square of $61 \%$ means that more than half COVID-19 death rate is explained by medical and demographic indicators such as number of people aged 70 older, diabetes prevalence and smokers. For Hypothesis 3 R-square equals $82,46 \%$ for June data set, which is a particularly good fit. It means that almost $82,5 \%$ of the variation in COVID-19 death rate is explained by the independent variables GDP per capita, hospital beds per thousand, and human development index. Unfortunately, in October economic factors have influenced COVID-19 death rate only by $66 \%$. The adjusted R-square shows the percentage of variation explained by only population density for Hypothesis 1, people aged 70 older, diabetes prevalence and smokers for Hypothesis 1, and GDP per capita, hospital beds per 1000, and human development index for Hypothesis 3. It is known that high R-square does not automatically show that the model has a good fit (Moksony, 1990). It is necessary to evaluate the R-square value in conjunction with other model statistics.

To check if the regression analysis results are reliable (statistically significant), look at significance $\mathrm{F}$ in table 2. It should be less than 0,05 . As it can be seen for Hypothesis 1 significance $F$ is greater than 0,05 in both data set in June and October. It is better not to use the independent variable population density (The Minitab Blog, 2013). So, Hypothesis 1 must be rejected.

Since the p-values for all variables are below 0,05 for both Hypothesis 2 and 3, it can be concluded that the regression model is a good fit for the data set in table 1 . All the coefficients are significant. Hypothesis 2 and 3 can be accepted. R square and adjusted $\mathrm{R}$-square indicates that a bigger deal of the variability COVID-19 death rate is captured by the model for Hypothesis 3 than for Hypothesis 2.

Similar calculations were carried out for other dates of the spread of COVID-19 in the software product STATISTICA. The results obtained differ slightly from those presented above. This allows us to conclude the indirect correlation between the level of economic development of the country and the death rate from the coronavirus indicator.

\section{Discussion}

It should be noted that best regression statistics for Hypothesis 3 does not mean that keeping social distance (Hypothesis 1) and high medical and demographic indicators (Hypothesis 2) does not contribute to a decrease of COVID-19 death rate.

Hypothesis 1 proposed to establish a relationship between the ability to maintain social distance, expressed in terms of population density and COVID19 death rate. The model statistics allow concluding that there is no such dependence. At the same time, many studies indicate that maintaining social distance has avoided almost 5 million new cases of COVID-19 infection in the US, 285 million new cases in China (Hsiang et al., 2020), and prevent 3,1 million deaths in Europe (Flaxman et al., 2020). All these studies were carried out using modeling techniques. If there were empirical data on the extent to which the inhabitants of the country observed social distance, then a regression analysis result for Hypothesis 1 could be different.

Hypothesis 2, which assumed that high medical and demographic rates contribute to a decrease in the COVID-19 death rate, was rejected. The article by N. Triggle (Triggle, 2020) raises the issue that the main victims of COVID-19 are the elderly people, and those with chronic health problems. These people are already chronically ill and therefore their death will not radically affect the mortality statistics. On the one hand, a regression analysis result for Hypothesis 2 confirms this fact. On the other hand, the COVID-19 pandemic is not over yet. This means that in the near future new medical and demographic indicators may be revealed. If to add them as independent variables to the regression equation (formula 2), then the relationship between them and the COVID19 death rate can be established.

There are enough articles devoted to the unreal difference in COVID-19 mortality between developed and developing countries. One of them (Schellekens, Sourrouille, 2020) raises the issue that developed countries account for more than half of the global population but for them, COVID-19 death rate is only $2 \%$. It was made simulations proved that the developing country share in global fatalities could rise by a factor of three (from 21 to 69\%). Data analysis for Hypothesis 3 also fully confirms simulations. 


\section{Conclusion}

Data analysis revealed that economic factors have a greater impact on the COVID-19 death rate in Europe than others.

To prove it 3 hypotheses were formulated. In Hypothesis 1 , it was assumed that the provision of social distance contributes to a decrease in COVID-19 death rate, in Hypothesis 2 - high medical and demographic indicators, and in Hypothesis 3 - high level of economic development. These hypotheses were summarized based on a literature review. Each of the hypotheses has its own followers and critics. To test the consistency of each hypothesis, the data analysis as a tool for assessing the factor's impact on the COVID-19 death rate was used. The analysis was carried out in 33 European countries. The choice of the hypothesis was based on regression analysis results.

From its result can be drawn such conclusions:

1. The density of the population of European countries is not a factor that impedes or contributes to the provision of social distance and does not in any way affect the COVID-19 death rate.

2. A regression analysis result confirmed the assertion that COVID-19 death rate will not drastically affect mortality statistics, since people who are already at risk are susceptible to the disease.

3. In developed countries, the pandemic death rate is lower, regardless of the mechanisms of the spread of the disease and its impact on human health.

But the autumn wave of coronavirus pandemic 2020 is different from the spring one. We can mention two big differences: an extremely higher level of contagiousness and a much lower level of mortality. In the future, it is important to develop the research of this topic for better understanding of all the features of the effects of coronavirus on mortality.

The generalized conclusion is that economically developed countries are investing in developing health care systems and improving public health. Over time, this leads to economic recovery and prosperity, since it is driven by healthy people who can work. The obtained results using the example of assessing the factor's impact on the COVID-19 death rate in Europe once again confirms the inseparability of the relationship between material well-being and public health.

\section{References}

1. AL-ROUSAN N., AL-NAJJAR H., 2020, Data analysis of coronavirus COVID-19 epidemic in South Korea based on recovered and death cases, in: Journal of Medical Virology, DOI: 10.1002/jmv.258506.

2. ALSADOON E., TURKESTANI M., 2020, Virtual classrooms for hearing-impaired students during the coronavirus COVID-19 pandemic, in: Revista Romaneasca pentru Educatie Multidimensionala, 12(1Sup2), p.1-8.

3. BARRO R.J., 2020, Macroeconomics, 5th ed, The MIT Press, $867 \mathrm{p}$.

4. BEREZHNA S., PROKOPENKO I., 2020, Higher education institutions in Ukraine during the coronavirus, or COVID-19, outbreak: new challenges vs new opportunities, in: Revista Romaneasca pentru Educatie Multidimensionala, 12(1Sup2), p. 130-135.

5. BRAGAZZI N.L., DAI H., DAMIANI G., BEHZADIFAR M., MARTINI M., WU J., 2020, How Big Data and Artificial Intelligence Can Help Better Manage the COVID-19 Pandemic, in: International Journal of Environmental Research and Public Health, 17, p. 3176, DOI: 10.3390/ijerph17093176.

6. BRAUER F., CASTILLO-CHAVEZ C., FENG Z., 2019, Mathematical Models in Epidemiology, Springer, $620 \mathrm{p}$.

7. CARAKA R.E., LEE Y., KURNIAWAN R., HERLIANSYAH R., KABAN P.A., NASUTION B.I., GIO P.U., CHEN R.C., TOHARUDIN T., PARDAMEAN B., 2020, Impact of COVID-19 large scale restriction on environment and economy in Indonesia, in: Global Journal of Environmental Science and Management, 6(SI), p. 65-84.

8. COHEN J., NORMILE D., 2020, New SARS-like virus in China triggers alarm, in: Science, 367(6475), p. 234-235.

9. CORONAVIRUS, 2020, Impact on the tourism industry worldwide, $117 \mathrm{p}$.

10. COVID-19 AND TOURISM, 2020, Assessing the economic consequences, $27 \mathrm{p}$.

11. COVID-19 (SARS-COV-2) VS INFLUENZA DATA, RESOURCES \& RESPONSE, 2020, https://smartnet.works/covid-19-sars-cov-2-vs-influenza $(30.10 .2020)$.

12. DLUHOPOLSKYI O., 2020. Pandemic 2020 and its impact on global economic development: the aviation industry crisis, in: Problems and perspectives of modern science and practice: Abstracts of XIV International Scientific and Practical Conference (27-28 April, 2020), Stockholm, p. 326-329.

13. DUA A., MAHAJAN D., OYER L., RAMASWAMY S., 2020, US small-business recovery after the COVID-19 crisis, https://www.mckinsey.com/industries/public-and-social-sector, (30.10. 2020).

14. EDUCATION AND COVID-19, 2020, Focusing on the long-term impact of school closures, OECD Policy Responses to Coronavirus (COVID-19). https://www.oecd.org/coronavirus/policy-responses, (30.X.2020).

15. FLAXMAN S., MISHRA S., GANDY A., UNWIN H.J., MELLAN T.A., COUPLAND H., WHITTAKER CH., ZHU H., BERAH T., EATON J.W., MONOD M., GHANI A.C., DONNELLY CH.A., RILEY S., VOLLMER M., FERGUSON N.M., OKELL L.C., BHATT S., 2020, Estimating the effects of nonpharmaceutical interventions on COVID-19 in Europe, in: Nature, DOI:10.1038/ s41586-020-2405-7.

16. FLORIZONE R., 2020, Three Ways the Coronavirus Is Shaping Sustainable Development, https://www. Iisd.org/articles/three-ways-coronavirus-shaping-sus tainable-development, (30.10.2020). 
17. FOLINAS S., METAXAS T., 2020, Tourism: The Great Patient of Coronavirus COVID-2019, MPRA Paper, Vol. 99666, https://mpra.ub.uni-muenchen.de/ 99666 (30.X.2020).

18. GLOBAL AVIATION MARKET 2020-2026: Report, https://www.researchandmarkets.com/reports/ 5129655 (30.X.2020).

19. GUPTA N., TOMAR A., KUMAR V., 2020, The effect of COVID-19 lockdown on the air environment in India, in: Global Journal of Environmental Science and Management, 6(SI), p. 31-40.

20. GURSOY D., CHI CH.G., 2020, Effects of COVID19 pandemic on hospitality industry: review of the current situations and a research agenda, In: Journal of Hospitality Marketing \& Management, 29(5), p. 527-529.

21. HAMIDI S., SABOURI S., EWING R., 2020, Does density aggravate the COVID-19 pandemic? Early findings and lessons for planners, in: Journal of the American Planning Association, DOI: 10.1080/ 01944363.2020.1777891.

22. HSIANG S., ALLEN D., ANNAN-PHAN S., BELL K., BOLLIGER I., CHONG T., DRUCKENMILLER H., HUANG L.Y., HULTGREN A., KRASOVICH E., LAU P., LEE J., ROLF E., TSENG J., W, T., 2020, The effect of large-scale anti-contagion policies on the COVID-19 pandemic, in Nature, DOI: 10.1038/ s41586-020-2404-8.

23. IATA, 2020, https://www.iata.org (30.X.2020).

24. INTER-AGENCY STANDING COMMITTEE, 2007, IASC Guidelines on Mental Health and Psychosocial Support in Emergency Settings, IASC: Geneva, $205 \mathrm{p}$.

25. JOHNS HOPKINS CRC, 2020, https://coronavirus. jhu.edu/region. (30.X.2020).

26. KLAPKIV Y., DLUHOPOLSKA T., 2020, Changes in the tertiary education system in pandemic times: comparison of Ukrainian and Polish universities, in: Revista Romaneasca pentru Educatie Multidimensionala, 12(1Sup2), p. 86-91.

27. KOZLOVSKYI S., BILENKO D., KUZHELIEV M., LAVROV R., KOZLOVSKYI V., MAZUR H., TARANYCH A., 2020, The system dynamic model of the labor migrant policy in economic growth affected by COVID-19, in: Global Journal of Environmental Science and Management, 6(SI), p. 95-106.

28. KOZLOVSKYI A., BILENKO D., KOZLOVSKYI S., LAVROV R., SKYDAN O., IVANYUTA N., 2020, Determination of the risk-free rate of return on an investment efficiency based on the fractal markets hypothesis, in: Forum Scientiae Oeconomia, 8(3), p. 61-72, http://ojs.wsb.edu.pl/index.php/fso/article/ view/316/247 (30.X.2020).

29. KOZIUK V., HAYDA Y., DLUHOPOLSKY O., KOZLOVSKYI S., 2020, Ecological performance: ethnic fragmentation versus governance quality and sustainable development, in: Problemy Ekorozwoju / Problems of Sustainable Development, 15(1), p. 5364.

30. MASUM M.H., PAL S.K., 2020, Statistical evaluation of selected air quality parameters influenced by COVID-19 lockdown, in: Global Journal of Environmental Science and Management, 6(SI), p. 85-94.

31. MINGHAT A.D., ANA A., PURNAWARMAN P., SARIPUDIN S., MUKTIARNI M., DWIYANTI V., MUSTAKIM, S.S., 2020, Students' perceptions of the twists and turns of e-learning in the midst of the
COVID-19 outbreak, in: Revista Romaneasca pentru Educatie Multidimensionala, 12(1Sup2), p. 15-26.

32. MOKSONY F., 1990, Small is beautiful. The use and interpretation of R2 in social research, in: Szociológiai Szemle, SI, 130-138.

33. MONTGOMERY D., PECK E., VINING G., 2012, Introduction to Linear Regression Analysis, 5th Edition, New-Jersey, Wiley, 688 p.

34. PAFKA E., 2020, As coronavirus forces us to keep our distance, city density matters less than internal density, The Conversation, https://theconversation. com (30.X.2020).

35. PORTA M., 2014, A Dictionary of Epidemiology, 5th ed., Oxford University Press: Oxford.

36. SANTI A.E., GORGHIU G., PRIBEANU C., 2020, Teachers' perceived self-efficacy concerning the use of mobile technology in education, considering the "Working from Home" format, in: Revista Romaneasca pentru Educatie Multidimensionala, 12(1Sup2), p. 157-166.

37. SCHELLEKENS P., SOURROUILLE D., 2020, COVID-19 mortality in rich and poor countries: a tale of two Pandemics? in: Policy Research Working Paper, 9260, p. 1-33.

38. STUKALO N., DLUHOPOLSKYI O., 2020, Educational programs accreditation in pandemic times: challenges for NAQA (Ukraine), in: Revista Romaneasca pentru Educatie Multidimensionala, 12(1Sup2), p. 167-172.

39. THE IMPACTS OF COVID-19 ON THE SPACE INDUSTRY, 2020, OECD Policy Responses to Coronavirus (COVID-19), https://www.oecd.org/ coronavirus/policy-responses (30.X.2020).

40. THE JOHNS HOPKINS CORONAVIRUS RESOURCE CENTER, 2020, https://coronavirus.jhu. edu/map.html (30.X.2020).

41. THE MINITAB BLOG, 2013, Regression Analysis: How Do I Interpret R-squared and Assess the Goodness-of-Fit?, https://blog.minitab.com/blog/adventur es-in-statistics-2 (30.X.2020).

42. THE POTENTIAL OF ONLINE LEARNING FOR ADULTS, 2020, Early lessons from the COVID-19 crisis. OECD Policy Responses to Coronavirus (COVID-19), https://www.oecd.org/coronavirus/policy-responses_(30.X.2020).

43. THE SUSTAINABLE DEVELOPMENT GOALS: OUR FRAMEWORK FOR COVID-19 RECOVERY, 2020, https://www.un.org/sustainabledevelopment (30.X.2020).

44. TOURISM POLICY RESPONSES TO THE CORONAVIRUS, 2020, OECD Policy Responses to Coronavirus (COVID-19), https://www.oecd.org/coronavirus/policy-responses (30.X.2020).

45. TRAN T.T., PHAM L.T., NGO Q.X., 2020, Forecasting epidemic spread of SARS-CoV-2 using ARIMA model (Case study: Iran), in: Global Journal of Environmental Science and Management, 6(SI), p. 1-10.

46. TRIGGLE N., 2020, Coronavirus: How to understand the death toll, BBC News, https://www.bbc.com/ news/health-51979654 (30.X.2020).

47. UNESCO, 2020, Solutions for distance learning, https://www.futureschool.online/post (30.X.2020).

48. WHO (WORLD HEALTH ORGANISATION), 2020, Assessment of risk factors for coronavirus disease 2019 (COVID-19) in health workers: protocol for a control study. 
49. WHO STATEMENT, 2020, Tobacco use and COVID-19, https://www.who.int/news-room (20.X. 2020).

50. WORLD BANK, 2020 World Bank Indicators, https://data.worldbank.org/indicator (20.X.2020).

51. WORLD BANK, 2020, WORLD BANK FIGHTING COVID-19: EUROPE AND CENTRAL ASIA ECONOMIC UPDATE, 2020. Washington, DC, 80 p., DOI: 10.1596/978-1-4648-1564-5.
52. WORLDOMETER, 2020, https://www.worldometers.info/coronavirus (20.X.2020)

53. XIE X., NAMINSE E.Y., LIU S., YI Q., 2020, The spatial and temporal pattern of COVID-19 and its effect on humans' development in China, in: Global Journal of Environmental Science and Management, 6(SI), p. 107-118.

54. YADAV D., MAHESHWARI H., CHANDRA U., 2020, Outbreak prediction of COVID-19 in most susceptible countries, in: Global Journal of Environmental Science and Management, 6(SI), p. 11-20. 